\title{
Evaluation of Operational Improvement Strategies to Reduce Congestion on Urban Corridors
}

\author{
Kaniz Fatima and Sara Moridpour \\ School of Civil Chemical \& Environmental Engineering, RMIT University, Melbourne, Australia
}

\begin{abstract}
In recent years, traffic congestion has become a major problem in transport networks particularly in peak periods. The congestion problem has become worse in large cities, particularly in the CBDs over the last few decades and the problem intensifies every year. Traffic congestion results in longer travel times, larger delays, more fuel consumptions and more emission. Australian Bureau of infrastructure, transport and regional economics estimates that the avoidable social costs of congestion will be more than doubled in 2020. This research intends to propose a solution to reduce traffic congestion and consequently traffic delay for a congested corridor in Melbourne metropolitan area. To achieve this, a number of strategies are introduced and their influence in traffic congestion is evaluated. Dedicated bus /tram lane, Bus/tram stop location change, Parking restriction, Bicycle lane restriction, Passenger car movement restriction, Lane configuration Advanced Green Signal and Extended Green signal will be applied to reduce congestion strategies. The site selected for this research is a corridor from inner suburbs of Melbourne.
\end{abstract}

\section{Introduction}

Traffic congestion problem in Australia may be the consequence of many factors. Congestion is generally worse in inner suburbs than outer area. A large number of commuters travel to/from work and school on same time intervals representing the most significant contributors of congestion. Rapid increase in population and cars are the key reasons of traffic congestion. Other key causes relating to both supply and demand side include underpricing of road use, lack of proper road infrastructure design/operation, travel demand growth and inadequate public transport alternatives. Traffic congestion is consequence of these factors. Therefore, effective demand management can reduce traffic congestions in urban areas. Congestion results in longer travel times, larger delays, more fuel consumptions and more emission. Time wasted in congestion has a huge cost for the society. The Texas Transport Institute (TTI) 2012 Urban Mobility Report reveals that U.S.A commuters wasted $\$ 5.5$ billion hours of extra time and fuel due to traffic congestion in 2011. This is equal to the amount of time that business and individual taxpayers spend lodging their tax applications. In Australia, the Australian bureau of infrastructure, transport and regional economics (BTRE) preliminary study estimates wastage of total $\$ 9.4$ billion as social cost of congestion for the year 2005 over the major Australian cities [1].
The aim of this research is to propose strategies to reduce traffic congestion in a particular corridor of Melbourne by modal management strategies. Corridor is a network of intersections. Melbourne is operating the largest tram network in the world. The tram system is a popular and convenient mode of transport in Melbourne. The case study corridor operates almost every mode of transport tram, bus, cars, pedestrian and bicycle. The research objectives are as follows:

a. Identify different strategies (i.e time and space priority for buses/trams) can be used to reduce traffic congestion and delay for different modes of transport.

b. Apply the strategies to a corridor in Melbourne as case study.

c. Analyse and compare the influence of different strategies on traffic congestion and delay of different modes of transport.

d. Propose better strategies to reduce congestion and travel delay.

\section{Background of research}

From literature review congestion management strategies can be defined as infrastructure expansion, congestion pricing management, modal congestion management. The study is focused on modal congestion management as it is the more economical solution than adding infrastructure and pricing congestion strategies [2].

\section{Aims and objectives}




\section{Research methodology}

The study intends to propose better strategies to control congestion for a selected corridor through SIDRA analysis. The steps are as follows:

\subsection{Modelling of the corridor in SIDRA}

Simulate the traffic conditions on four intersections with same number of lanes, traffic volume, bus/tram frequency and signal cycle time. In the case of any differences of actual network condition and SIDRA simulated intersection model, input parameters need to be calibrated. If the observed intersection condition and SIDRA simulated intersection model is similar, the SIDRA model can identified as a validated model.

\subsection{Identifying of different strategies}

Identify different modal congestion management strategies to reduce traffic congestion. Space priority for trams/buses at intersection/corridor is one of the proposed and applied strategies in different cities. Modifying signal time (i.e extended green or early green signal) during peak periods of the day is another applied strategy to control traffic congestion. Parking restrictions and removal of bicycle lanes are also utilized to reduce congestion around different intersections.

\subsection{Simulation of different strategies}

Provide priority to only bus/tram or any other strategy is not effective. The research will simulate different identified strategies to see the effect on intersections and corridor/network. The study will apply each strategy on intersection to see the effect of congestion.

\subsection{Comparison of applied strategies}

The study will compare simulated models of network/corridor with present conditions and propose better methods to control congestion. Three main parameters travel speed, queue length and average delay will be used to compare strategies.

Table 1. Summary of intersection grouping

\begin{tabular}{|c|c|}
\hline Intersection Name & $\begin{array}{c}\text { Site Grouping according } \\
\text { to VicRoads. }\end{array}$ \\
\hline $\begin{array}{c}\text { Princess Street/Studley } \\
\text { Street/High Street South/ } \\
\text { Denmark Street/High Street }\end{array}$ & 3662 \\
\hline $\begin{array}{c}\text { Denmark Street/Wellington } \\
\text { Street }\end{array}$ & 3663 \\
\hline $\begin{array}{c}\text { Denmark Street/Stevenson } \\
\text { Street }\end{array}$ & 1190 \\
\hline $\begin{array}{c}\text { Denmark Street/Power } \\
\text { Street/Barkers Road }\end{array}$ & 3002 \\
\hline
\end{tabular}

\section{Study area}

The study corridor starts from Manningtree Road and Power Street intersection to the intersection of Princes
Street and Beatrice Street (M21, Melways Ref: 45, C11Street Directory) in Melbourne, Australia. The corridor is about $2.1 \mathrm{~km}$ long which approaches various lanes per direction. The daily traffic volume of the corridor is (annual average) 7, 91, 013 per day. The corridor includes fifteen different intersections.

Table 1 represents the summary of intersection grouping name provided by VicRoads. The numbers are used althrough the research to identify the intersections.

\section{Datasets for corridor simulation}

Datasets have been collected from five different sources for one hour morning peak period. Table 2 represents the summary of collected data.

Table 2. Summaries of collected datasets.

\begin{tabular}{|c|c|c|c|}
\hline \multicolumn{4}{|c|}{ Data Sets (From 7.30 AM to $8.30 \mathrm{AM}$ ) } \\
\hline VicRoads & Site Survey & $\begin{array}{c}\text { Yarra } \\
\text { trams/Bus } \\
\text { system } \\
\text { Information } \\
\end{array}$ & $\begin{array}{c}\text { Google } \\
\text { Maps }\end{array}$ \\
\hline 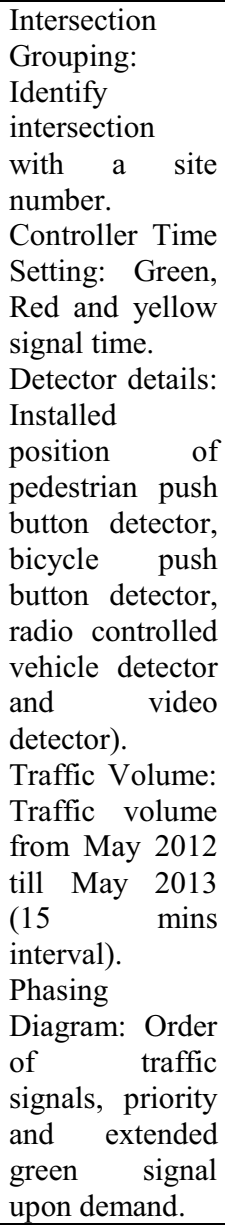 & $\begin{array}{l}\text { Intersection } \\
\text { Geometric } \\
\text { details: } \\
\text { Lane no, } \\
\text { length, } \\
\text { width, } \\
\text { approaches } \\
\text { for vehicle } \\
\text { and bicycle. } \\
\text { Movement: } \\
\text { Straight/left/ } \\
\text { right, } \\
\text { restriction. } \\
\text { Speed: } \\
\text { Speed limit } \\
\text { for all } \\
\text { approaches. } \\
\text { Average } \\
\text { Speed: } \\
\text { Average } \\
\text { speed, travel } \\
\text { time and } \\
\text { back of } \\
\text { queue have } \\
\text { been } \\
\text { measured } \\
\text { for all } \\
\text { approaches } \\
\text { to validate } \\
\text { of the } \\
\text { corridor } \\
\text { model. }\end{array}$ & $\begin{array}{l}\text { Time table } \\
\text { and frequency } \\
\text { for buses. } \\
\text { Time table } \\
\text { and frequency } \\
\text { for trams. }\end{array}$ & $\begin{array}{l}\text { Distance } \\
\mathrm{s} \\
\text { between } \\
\text { intersect } \\
\text { ion }\end{array}$ \\
\hline
\end{tabular}

\section{Model development}

Micro simulation models contain a number of independent parameters to describe traffic control operation, traffic flow characteristics and drivers' behaviour. These models contain default values for each variable but they also allow users to input values. 
Changes of these parameters during calibration should be based on field-measured conditions and should be justified by the users [3][4]. SIDRA Intersection version 6 has a number of input and output parameters to model and validate model. To configure the corridor each intersection has to model separately according to the datasets [5][6]. Output results will produce on table and layout format. The output results can form for individual approaches, intersections and networks.

\subsection{Calibrated parameter}

Saturation flow rate: The flow rate of vehicle per lane at which vehicles can pass through a signalized intersection if the signal remains green all the time.

Critical gap: The travel time for following vehicle that can reach to immediate front vehicle on signal.

Follow up headway: The travel time for following vehicle that can reach to immediate front vehicle on move.

SIDRA presents a number of parameters for output results. Three main parameters, travel speed, delay average and queue distances are calibrated for each intersection. Origin-destination (OD) trip matrices volume is applied for this network volume along the corridor [7][8][9][10][11]. Main three parameters travel speed, delay average and queue length has been calibrated with actual datasets for this network/corridor. The network is validated and ready for the application of strategies.

\subsection{Level of Service (LOS)}

The level of service (LOS) of the simulated intersections is the main target. Strategies can be applied on worst LOS lane to reduce congestion. Intersection 3662 is the most congested intersection of this corridor. Table 3 represents the summary of LOS.

Table 3. Summary of LOS.

\begin{tabular}{|c|c|c|c|c|c|c|}
\hline \multicolumn{7}{|c|}{ Summary of LOS for Intersection 3662} \\
\hline $\begin{array}{c}\text { Denmark } \\
\text { St }\end{array}$ & High St & \multicolumn{2}{|c|}{$\begin{array}{c}\text { Princess } \\
\text { St }\end{array}$} & \begin{tabular}{|c|} 
Studley \\
St
\end{tabular} & $\begin{array}{l}\text { High St } \\
\text { south }\end{array}$ & Intersection \\
\hline $\mathrm{D}$ & $\mathrm{E}$ & \multicolumn{2}{|c|}{$\mathrm{D}$} & $\mathrm{C}$ & $\mathrm{E}$ & $\mathrm{D}$ \\
\hline \multicolumn{7}{|c|}{ Summary of LOS for Intersection 3663} \\
\hline $\begin{array}{c}\text { Denmark } \\
\text { St, } \\
\text { South }\end{array}$ & \multicolumn{2}{|c|}{$\begin{array}{c}\text { Wellington } \\
\text { St }\end{array}$} & \multicolumn{3}{|c|}{$\begin{array}{l}\text { Denmark St, } \\
\text { North }\end{array}$} & Intersection \\
\hline $\mathrm{B}$ & \multicolumn{2}{|l|}{$\mathrm{C}$} & \multicolumn{3}{|c|}{$\mathrm{C}$} & $\mathrm{C}$ \\
\hline \multicolumn{7}{|c|}{ Summary of LOS for Intersection 1190} \\
\hline $\begin{array}{c}\text { Denmark } \\
\text { St, } \\
\text { South }\end{array}$ & \multicolumn{3}{|c|}{ Denmark St, North } & \multicolumn{2}{|c|}{$\begin{array}{c}\text { Stevenso } \\
\mathrm{n} \mathrm{St}\end{array}$} & Intersection \\
\hline $\mathrm{B}$ & \multicolumn{3}{|c|}{$\mathrm{B}$} & \multicolumn{2}{|c|}{$\mathrm{B}$} & $\mathrm{B}$ \\
\hline \multicolumn{7}{|c|}{ Summary of LOS for Intersection 3002} \\
\hline Power St & $\begin{array}{r}\text { Barke } \\
\mathrm{Rd}, \mathrm{Ea}\end{array}$ & & Den & $\begin{array}{l}\text { lamrk } \\
\text { St }\end{array}$ & $\begin{array}{c}\text { Barker } \\
\text { Rd, } \\
\text { West }\end{array}$ & Intersection \\
\hline $\mathrm{D}$ & $\mathrm{C}$ & & & $\mathrm{D}$ & $\mathrm{D}$ & $\mathrm{D}$ \\
\hline
\end{tabular}

\section{Applied strategies on corridor}

From literature review modal management strategies can be apply on this corridor as follows:

- Priority for buses and trams

- Remove bicycle lanes

- Change lane configuration

- Restrict movements

- Change locations of tram stops

- Signal Cycle Change

The strategies will be applied on intersections separately. Better individual resultant strategies will apply on network/corridor and simulate to determine the best strategies. Table 4 represents the summary of applied and efficient strategies for each intersection.

Table 4. Summary of applied and efficient strategies

\begin{tabular}{|c|c|c|c|c|}
\hline \multicolumn{5}{|c|}{ Applied Strategies on Site } \\
\hline 3662 & & 3663 & 1190 & 3002 \\
\hline $\begin{array}{l}\text { - Movement } \\
\text { Restriction } \\
\text { - Change of } \\
\text { Phase time } \\
\text { and phase } \\
\text { order } \\
\text { - Tram Stop } \\
\text { relocation } \\
\text { from High St } \\
\text { to High St } \\
\text { south } \\
\text { Bicycle lane } \\
\text { restriction } \\
\text { - Lane } \\
\text { Configuration }\end{array}$ & $\begin{array}{r}\text { - } \mathrm{L} \\
\mathrm{C} \\
\mathrm{C} \\
\mathrm{la} \\
\mathrm{la} \\
\mathrm{St} \\
\mathrm{si} \\
\mathrm{or} \\
\text { - } \mathrm{P} \\
\mathrm{R} \\
\mathrm{C} \\
\mathrm{la} \\
\mathrm{W} \\
\text { - C } \\
\mathrm{pl}\end{array}$ & $\begin{array}{l}\text { ee } \\
\text { nfiguration: } \\
\text { nfigure parking } \\
\text { e to an exit } \\
\text { e at Wellington } \\
\text { and changed } \\
\text { hal phase } \\
\text { er. } \\
\text { king } \\
\text { triction: } \\
\text { nfigure parking } \\
\text { e to exit lane at } \\
\text { llington St. } \\
\text { anged signal } \\
\text { se order. }\end{array}$ & $\begin{array}{l}\text { Chang } \\
\text { ed } \\
\text { signal } \\
\text { phase } \\
\text { order. }\end{array}$ & $\begin{array}{l}\text { Chang } \\
\text { ed } \\
\text { signal } \\
\text { phase } \\
\text { order. }\end{array}$ \\
\hline \multicolumn{5}{|c|}{ Efficient Strategies for Sites } \\
\hline 3662 & & 3663 & 1190 & 3002 \\
\hline $\begin{array}{l}\text { - Change of phas } \\
\text { time and phase } \\
\text { order. } \\
\text { - Movement } \\
\text { restriction: } \\
\text { 1. Restrict } \\
\text { movement fron } \\
\text { Denmark St tov } \\
\text { High St South. } \\
\text { 2. Restrict } \\
\text { Movement fron } \\
\text { High St south } \\
\text { towards Princes } \\
\text { and from Denm } \\
\text { St towards Hig } \\
\text { South. } \\
\text { - Lane Configura } \\
\text { 1. Restrict High } \\
\text { South towards } \\
\text { Princess St and } \\
\text { Princess St tow } \\
\text { High St South. } \\
\text { 2. Restrict High } \\
\text { lane1 towards } \\
\text { Studley and fro } \\
\text { Denmark St tov } \\
\text { High St South. }\end{array}$ & $\begin{array}{l}\text { St } \\
\text { rk } \\
\text { St } \\
\\
\text { lon: } \\
\text { St }\end{array}$ & $\begin{array}{l}\text { - Parking } \\
\text { Restriction: } \\
\text { Configure } \\
\text { parking lane } \\
\text { to exit lane } \\
\text { at } \\
\text { Wellington } \\
\text { St. } \\
\text { - Changed } \\
\text { signal phase } \\
\text { order. }\end{array}$ & $\begin{array}{l}\text { Chang } \\
\text { ed } \\
\text { signal } \\
\text { phase } \\
\text { order. }\end{array}$ & $\begin{array}{l}\text { Site } \\
3002 \\
\text { Intersec } \\
\text { tion has } \\
\text { less } \\
\text { congesti } \\
\text { on } \\
\text { during } \\
\text { morning } \\
\text { peak } \\
\text { period. } \\
\text { Applied } \\
\text { strategie } \\
\text { s for } \\
\text { signal } \\
\text { phase } \\
\text { order } \\
\text { change } \\
\text { do not } \\
\text { affect } \\
\text { the } \\
\text { intersect } \\
\text { ion. }\end{array}$ \\
\hline
\end{tabular}




\section{Efficient strategies for case study}

1. Modify signal phase order for intersection 3662 and other three intersections can operate according to present condition.

2. Movement restriction from High Street South to Princess Street and from Princess Street towards High Street South at intersection 3662 and other three intersections kept same as present.

3. Configure parking lane to exit lane at Wellington Street.

Fig. 1 represents travel speed comparison of efficient strategy $1 \& 2$. Traffic condition improves for first through efficient strategies application. Arrows on layout shows vehicle movement direction. Numbers in black is the simulate value for travel speed. Percentage number in blue indicates the improvement of each direction.

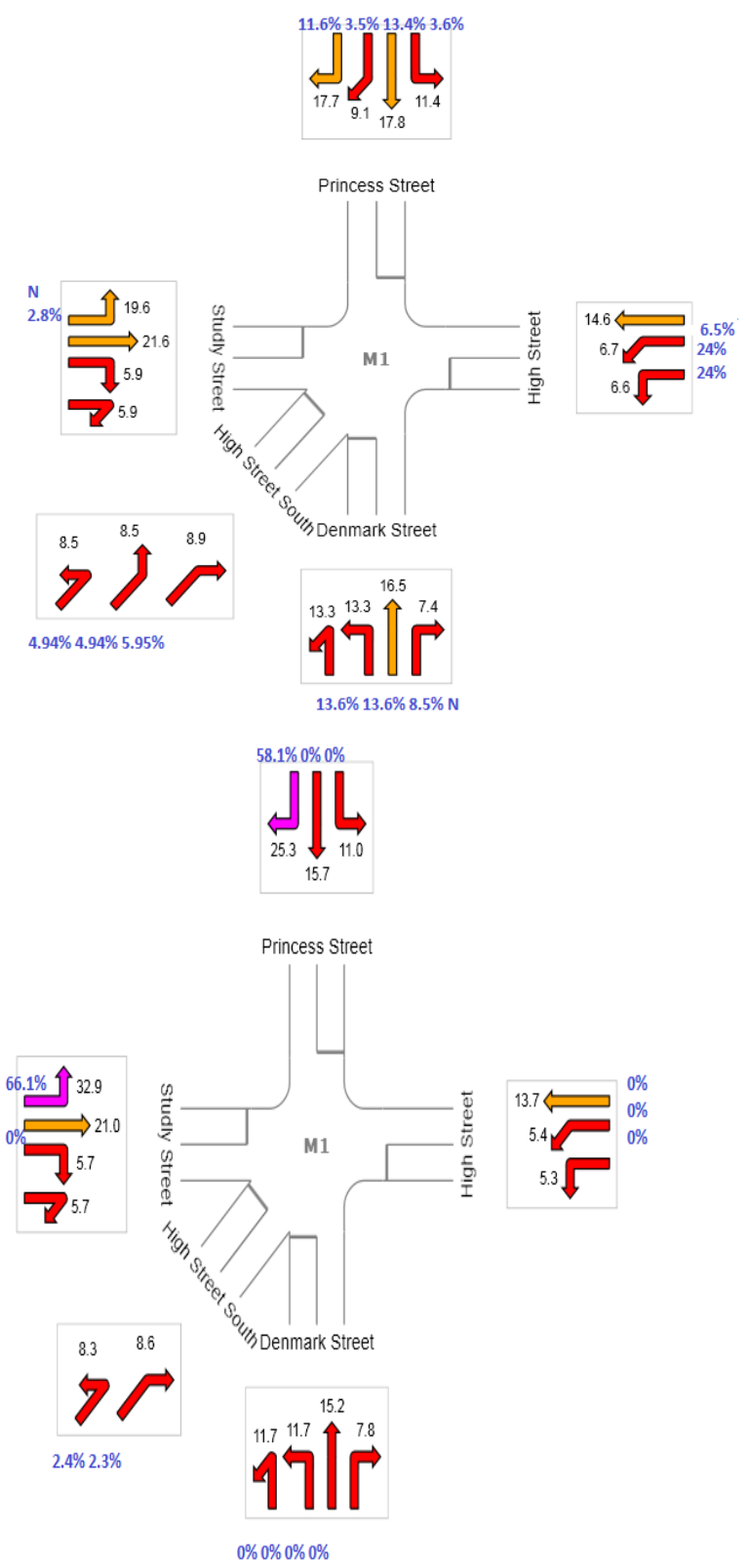

Figure 1. Travel speed comparison strategy $1 \&$ strategy 2.

Fig. 2 represents queue distance comparison of efficient strategy $1 \& 2$. Traffic condition improves for first through efficient strategies application. Arrows on layout shows vehicle movement direction. Numbers in black is the simulate value for travel speed. Percentage number in blue indicates the improvement of each direction.

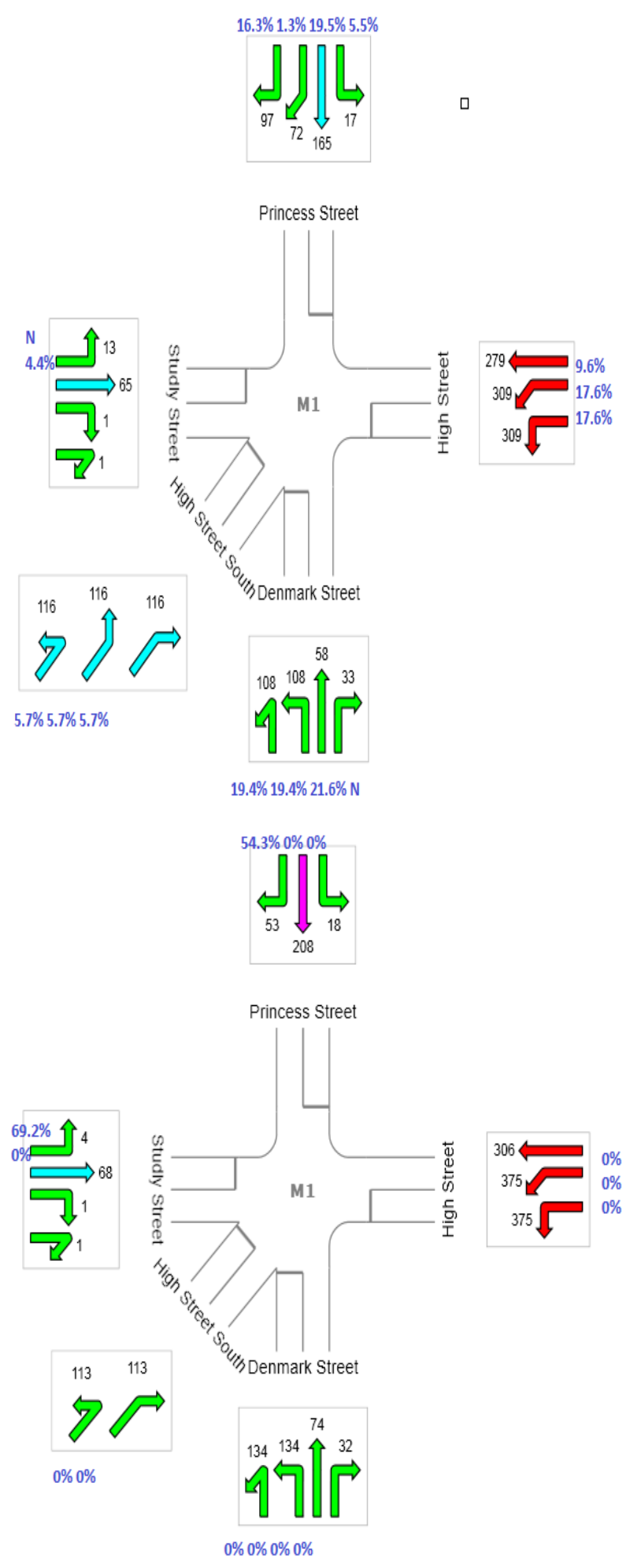

Figure 2. Queue distance comparison strategy 1\& strategy 2.

Again Fig. 3 represents delays comparison of efficient strategy $1 \& 2$. Traffic condition improves for first through efficient strategies application. Arrows on layout shows vehicle movement direction. Numbers in black is 
the simulate value for travel speed. Percentage number in blue indicates the improvement of direction.
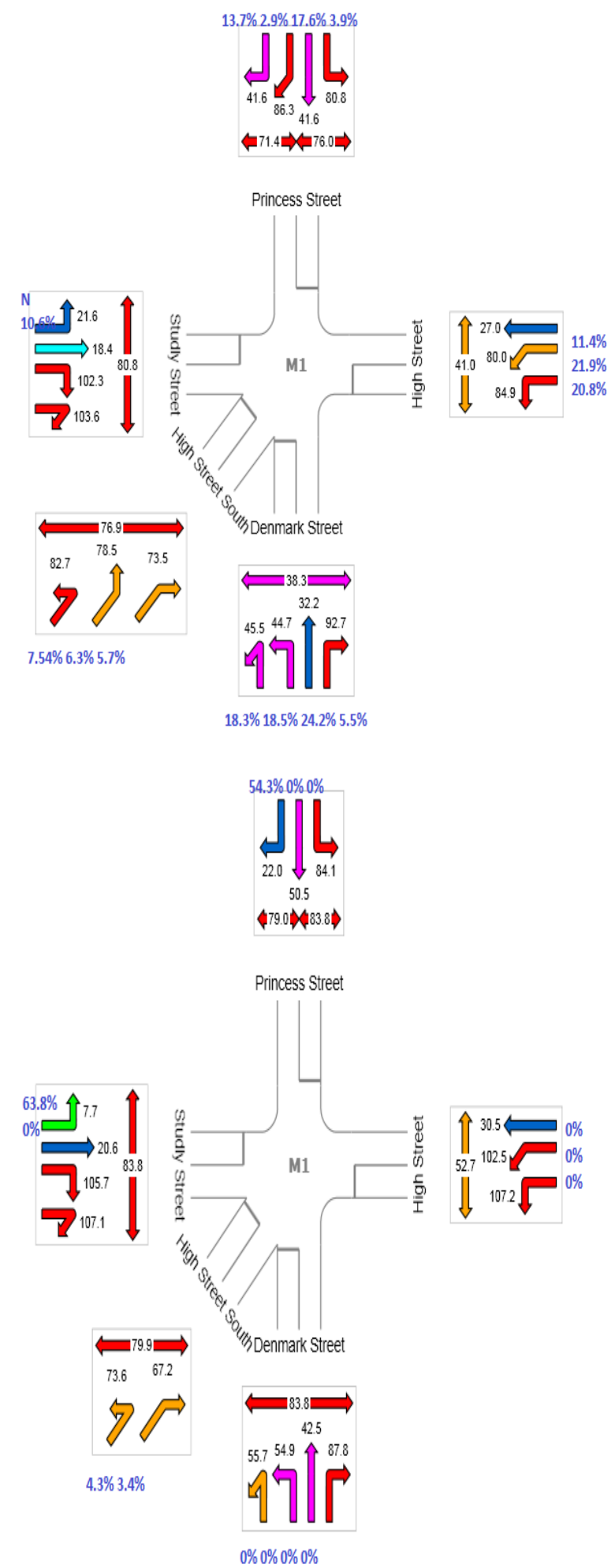

Figure 3. Delays average comparison strategy $1 \&$ strategy 2 .

Table 5 shows comparison of output parameters after simulation as a network or corridor. Observed values have been collected from site survey. Applying the strategies improved network operation. Travel speed has been increased. Travel time, delay and cost decreased. Modification of signal phase order and cycle is more effective than movement restriction.
Table 5. Summary of network output parameter comparison.

\begin{tabular}{|l|l|l|l|}
\hline $\begin{array}{l}\text { Output } \\
\text { Parameter }\end{array}$ & $\begin{array}{l}\text { Observed } \\
\text { Network }\end{array}$ & $\begin{array}{l}\text { Strategy 1 } \\
\text { Network }\end{array}$ & $\begin{array}{l}\text { Strategy 2 } \\
\text { Network }\end{array}$ \\
\hline $\begin{array}{l}\text { Travel Speed, } \\
\text { km/h }\end{array}$ & 19.8 & $20.7(4.5 \%)$ & $20.3(2.5 \%)$ \\
\hline $\begin{array}{l}\text { Travel Time } \\
\text { (Total), veh-h/h }\end{array}$ & 219.8 & $210.0(-4.4 \%)$ & $214.1(-2.5 \%)$ \\
\hline $\begin{array}{l}\text { Travel Delay, } \\
\text { sec }\end{array}$ & 42.0 & $39.3(-6.4 \%)$ & $40.4(-3.8 \%)$ \\
\hline $\begin{array}{l}\text { Control Delay } \\
\text { (Total), veh-h/h }\end{array}$ & 128.26 & $119.31(-6.9 \%)$ & $123.14(-3.9 \%)$ \\
\hline $\begin{array}{l}\text { Congestion Co- } \\
\text { efficient }\end{array}$ & 3.03 & $2.90(-4.3 \%)$ & $2.95(-2.6 \%)$ \\
\hline Cost (Total), \$/l & 7622.78 & $7273.90(-4.8 \%)$ & $7447.17(-2.3 \%)$ \\
\hline
\end{tabular}

\section{Conclusion}

Two best strategies have been identified to control congestion of this corridor. Time priority and movement restriction is the two best strategies for this corridor. Parking restriction for morning peak period on Wellington street intersection also increase the LOS of this corridor. Parking restriction on Wellington street increase the corridor traffic condition but it also has a minimal bad effect on Wellington Street and Stevenson Street. As these two streets are not congested and highly traffic volumed. Parking restriction on Wellington street during morning peak period can consider one of the proposed strategies. The study proposes several individual strategies which increased travel speed but decreases travel time. For $\mathrm{T}$-intersection rearrange of signal phase can be efficient. Again for busy intersection with more than four approaches movement restriction and lane configuration improves the intersection as well as corridor performance.

In future the research can continue applying strategies on different intersections and roundabout. To control congestion with modal management strategies more intersections can be simulated. The research can direct as follows:

- More intersections can be added to simulate larger corridor.

- Adjoin simulated corridor as a network and apply strategies to see the effect.

- Adjoin signalised, un-signalised and roundabout and simulate strategies.

\section{References}

1. Transport, A. $w p \_071 . p d f .(2007)$.

2. J. Leonardo, C. Angelo G. Antonio Gschwendera, M.Fusterb Basso, L. J., et al. Congestion pricing, transit subsidies and dedicated bus lanes: Efficient and practical solutions to congestion. Transport Policy 18(5): 676-684.4(2011).

3. B. Park. Microscopic simulation model calibration and validation.pdf. Transportation Research Record: Journal of the Transportation Research Board, 1856/2003, 185-192 (2003). 
4. B.P.H. Qi. Microscopic simulation model calibration and validation for freeway work zone network.pdf. Intelligent Transportation Systems Conference, 2006. ITSC '06. IEEE, 1471 - 1476, (2006).

5. R. Akcelik. Fundametal traffic varriables in adaptive controland the SCATS DS parameter.pdf. 3rd International conference ITS Australia, (1997).

6. R. Akcelik. An Improved Method for Estimating Sign-Controlled Intersection Capacity.pdf. New Zealand Modelling User Group NZMUGS 2012 Conference. Auckland, (Sep 2012).

7. G.-L. Chang \& J. Wu. Recursive estimation of timevarying origin-destination flows from traffic counts in freeway corridors. Transportation Research Part B: Methodological, 28, 141-160, (1994).
8. M. Cremer. A new class of dynamic methods for the identification of origin-destination flows.pdf. Transport Research Board, 21B, 117-132, (1986).

9. H. Yang, T. Sasaki, Y. Iida, \& Y. Asakura. Estimation of origin-destination matrices from link traffic counts on congested networks. Transportation Research Part B: Methodological, 26, 417-434, (1992).

10. A. Medina, N. Taft, K. Salamatian, S. Bhattacharyya, C. Diot. Traffic Matrix Estimation: Existing Techniques and New Directions, (2002).

11. M. Papageorgiou. Dynamic modeling, assignment, and route guidance in traffic networks. Transportation Research Part B: Methodological, 24, 471-495, (1990). 